\title{
Quantifying in Situ Horizontal Stress in the Niger Delta Basin, Nigeria
}

\author{
E. O Adewole and D. Healy
}

\begin{abstract}
We have determined the direction and the magnitude of the two horizontal stress components (minimum and maximum) in the Niger Delta Basin, Nigeria from petroleum exploration data from the region. Faults interpreted from a high fold 3D seismic data imply a dominant normal faulting regime. It suggests that maximum horizontal stress $\left(\mathrm{SH}_{\max }\right)$ is an intermediate principal stress in the basin. The magnitude of the horizontal stress is quantified by two methods: as a function of vertical stress and as a function of overpressure at depth. The scattering of $\mathrm{SH}_{\min }$ values estimated from application of the Eaton (1969) method and Leak Off Test (LOT) data is indicative of the $\mathrm{SH}_{\min }$ gradient varying with depth in the basin. We propose an inhomogeneous stress field and more than one source of stress in the region based on the result of multiple directions determined from the analysis of 32 borehole breakouts recorded in six wells. We suggest the occurrence of repeated earth tremors in the region is likely to be due to the reactivation of rifted continental crust linking the regional onshore faults along major lineaments.
\end{abstract}

Index Terms - maximum horizontal stress, borehole breakouts in Niger Delta Basin, seismicity in Niger Delta Basin, minimum horizontal stress.

\section{INTRODUCTION}

Quantifying the minimum horizontal stress $\left(\mathrm{SH}_{\min }\right)$ is a critical step in determining the full stress tensor, and provides vital information for the location of $\mathrm{CO}_{2}$ storage facilities and for drilling stable wells. In an overpressured region, such as the Niger Delta, a small difference can exist between the pressure and the $\mathrm{SH}_{\min }$ magnitudes that will determine the range of pressure to use while drilling (Zoback, 2010). Variations of $\mathrm{SH}_{\text {min }}$ magnitudes are more controlled by tectonic stress and pore pressure than variations in the magnitude of vertical stress $\left(\sigma_{\mathrm{v}}\right)$ (Engelder, 1993; Tingay et al., 2003). The orientation and magnitude of the principal stresses controls estimates of fault stability and maximum sustainable pore fluid pressure beyond which new faults are created or existing faults reactivated. A higher pore fluid pressure decreases the resistance to sliding and increases proximity of a fault to failure. The orientation of

Manuscript received October 31, 2013. The authors acknowledge the financial support in this work provided by the Niger Delta Development Commission (NDDC), Nigeria as part of the initiatives of the corporation to develop the energy sector in Nigeria.

E. O Adewole is a PhD student of Geology and Petroleum Geology Department, School of Geosciences, King's College, University of Aberdeen, AB24 3UE, UK (phone: +44(0)7589405181; e-mail: o.adewole@ abdn.ac.uk).

D. Healy is a Senior Lecturer at the Department of Geology and Petroleum Geology, School of Geosciences, King's College, University of Aberdeen, AB24 3UE, UK (phone: +44 (0)1224 273850 ; e-mail: d.healy@abdn.ac.uk). a fault and the magnitude of the local stresses are some of the critical factors that determine if an increase in pore fluid pressure will lead to creation of new fractures or the reactivation of an existing fault.

In this study, petroleum exploration data (seismic and well data) from the Niger Delta Basin, Nigeria have been analysed in order to investigate the local variability of the in situ horizontal stress. Faults interpreted from 48 fold 3D seismic dataset, which provide ideal information for geomechanical modeling (Streit and Hillis, 2004), were used to determine the type of faults and their orientations in the study area. Applications of stress data require a continuous profile of stress with depth (Zoback, 2010). The challenges of inadequate stress data in our analysis, such as the absence of higher accuracy Drilling Induced Tensile Fractures (DITFs) data, frictional limit to stress, mini fracture (mini-frac) and borehole images such as Formation Micro Imager (FMI) and Formation Micro Scanner (FMS), were ameliorated by using the Eaton (1969) and Holbrook (1993) methods and then comparing the results with baseline stress data from other basins worldwide (Breckels, 1981). The non-availability of accurate stress data for research is perhaps partly responsible for the lack of adequate stress data in the West Africa region as shown on the World Stress Map (Fig. 1). A substantial number of the Leak Off Tests (LOTs) carried out in the field were not successful due to seal breakage and bad data interpretation at the well site (this study; Mark Tingay, personal communication). The orientation of the maximum horizontal stress has been determined from borehole breakouts interpreted from four-arm caliper data recorded in six wells. The estimation of stress carried out in this study did not cover depleted oil and gas fields. The reason is in part due to the absence of pre-production stress data induced by long years of hydrocarbon production and data associated with pore pressure depletion.

\section{GeOlogical SETTING}

Several researchers have described the depositional and tectonic history of the Niger Delta Basin (Hospers, 1965, 1971; Stoneley, 1966; Short and Stauble, 1967; Weber, 1971, 1987; Burke et al., 1972; Merki, 1972; Weber and Daukoru, 1975; Evamy et al., 1978; Whiteman, 1982). The continuation of the same stratigraphic units and the steep gradients of the rocks from the Anambra to the Niger Delta Basin (NDB) suggest development of the NDB from the Anambra Basin in the Late Cretaceous. There was a significant increase in the 
sedimentation rate from the Eocene to the present day by regressive cycles with minor transgressions which accelerated the development of the basin far into the Atlantic Ocean (Merki, 1972; Weber and Daukoru, 1975). Three main lithological units have been identified in the basin (Short and Stauble, 1967; Avbovbo, 1978; Doust and Omatsola, 1990). The topmost Benin Formation contains unconsolidated sands. The underlying Agbada Formation, which serves as the main reservoir rock for hydrocarbons in the basin, comprises intercalated sands and shales with a great potential to develop overpressure with depth. The lowest and oldest lithological unit is the Akata Formation which consists of under-compacted, overpressured, thick, prodeltaic marine shale. The entire NDB has concentrations of syndepositional growth faults that increase in steepness toward the Atlantic (Tuttle et al., 1999).

A few seismic events have been recorded in some locations outside the NDB (e.g. Accra and Kribi) along the continental margin (Ambraseys and Adams, 1986). Burke (1971) did not agree that recent tectonic events were related to the movement along the oceanic transform faults, based on the long distance between the mid oceanic ridge to the continental margin; instead he attributed the seismicity to the sudden changes in crustal thickness at the faulted continental margin. If the oceanic fracture zones are weak, the high in situ stress from the mid-oceanic faults is expected to distribute to the continental areas which will eventually increase the frequency of the seismicity and probably spread out to other areas with no record of significant seismicity. However, there is a need to provide adequate stress data that will cover the region to help resolve these issues, which at the moment are not available.

\section{ESTIMATION OF MINIMUM HORIZONTAL STRESS MAGNITUDE}

Bell (1996) and Reynolds (2006) suggested the use of hydraulic fracturing (mini-frac) and LOT data to constrain the magnitude of $\mathrm{SH}_{\min }$ in petroleum basins. Mini-frac data have been reported to be more accurate for estimating $\mathrm{SH}_{\min }$ than LOT data (Streit and Hillis, 2004; Reynolds et al., 2006). However, mini-frac tests are not usually carried out in the study area (NDB) because one of the primary aims is to boost production in very low permeability reservoirs and significant reservoir porosities up to $30 \%$ have been observed in the basin (this study). Thus, acquisition of mini-frac data is less attractive to petroleum exploration companies. The lower limit

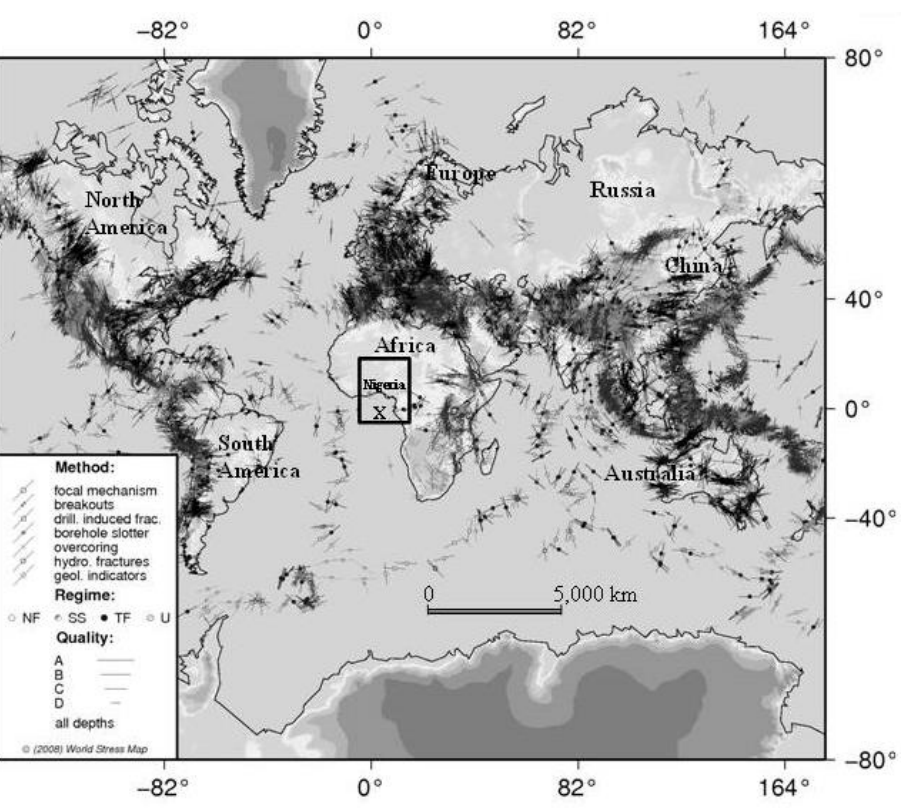

Fig. 1. Location of Niger Delta Basin, Nigeria showing the study area and data pertaining to stress directions, sources and regimes from world stress map (Heidbach, O., Tingay, M., Barth, A., Reinecker, J., quality and long arrow $=$ higher quality). Despite the wide range of the publishable stress data quality ( $A, B$ Nigeria.

to leak off pressures in vertical wells gives an estimate of the $\mathrm{SH}_{\text {min }}$ (Bell, 1990, Breckels; Reynolds, 2006). We used the Eaton (1969) and Holbrook (1993) methods to calculate $\mathrm{SH}_{\min }$ for comparison because elevated overpressures have been observed in the basin (this study). The formula used for the Eaton (1969) method is:

$$
\text { Eaton SHmin }=[v / 1-v]\left(\sigma_{\mathrm{v}}-\mathrm{Pp}\right)+\mathrm{Pp}
$$

Where $\mathrm{P}_{\mathrm{p}}$ is the pore fluid pressure and $v$ is the Poisson ratio, equal to $\mathrm{P}$-wave velocity $\left(\mathrm{V}_{\mathrm{p}}\right) / \mathrm{S}$-wave velocity $\left(\mathrm{V}_{\mathrm{s}}\right)$ and was calculated from well W24 that has shear wave $\left(\mathrm{V}_{\mathrm{s}}\right)$ data. Sibson (1974) associated the required shear stress to cause a failure to a ratio between the maximum and minimum principal stresses:

\section{$\sigma_{1} / \sigma_{2} \leq$ Coefficient of friction}

In a normal faulting regime where $\sigma_{\mathrm{v}}$ is the maximum principal stress andcSH $\mathrm{Sm}_{\min }$ is the minimum principal stress (Anderson, 1951), the stress ratio becomes:

SHmin $/ \sigma_{\mathrm{v}}=\sigma_{1} / \sigma_{3}$

The effective stress counterparts of $\sigma_{1}$ and $\sigma_{3}$ are $\sigma_{1}-p_{p}$ and $\sigma_{3}-$ $\mathrm{p}_{\mathrm{p}}$ respectively. The Poisson ratio, the depth varying function in (1), is defined as:

$$
v / 1-v=\operatorname{SHmin} / \sigma_{\mathrm{v}}=T
$$

Thus, Eaton $\mathrm{SHmin}=T\left(\sigma_{\mathrm{v}}-\mathrm{Pp}\right)+\mathrm{Pp}$

"T" varies from 0.33 at $3 \mathrm{~km}$ to 0.5 at $6 \mathrm{~km}$ depth (this study). 
Holbrook (1993) replaced the empirical constant $\mathrm{T}$ in the Eaton equation (2) with a porosity based function as discussed below.

Holbrook $\mathrm{SH}_{\min }=[1-\varnothing]\left(\sigma_{\mathrm{v}}-\mathrm{Pp}\right)+\mathrm{Pp}$

Thus, the accuracy of the Holbrook method hinges on the availability of good porosity data. In this study, porosities from core data were used in selected intervals from 3,000 to 3,800 $\mathrm{m}$ but the $\mathrm{SH}_{\min }$ value was still overestimated in the depth interval as shown in Fig. 2, suggesting the failure of the method in this part of Niger Delta Basin.

Mini-frac data from the US Gulf Coast have been suggested to fit with those from other parts of the world (Breckels et al., 1981), but because of the differences in the average overburden densities between tectonically active and relaxed regions, Breckels et al. (1981) suggested the following 2 relationships for a tectonically relaxed region such as the NDB:

Breckels $\mathrm{SH}_{\min }$ for depth less than $~ 3,505 \mathrm{~m}=0.197 \mathrm{D} 1.145+$ $0.46\left(\mathrm{Pp}-\mathrm{P}_{\mathrm{cn}}\right)$

Breckels $\mathrm{SH}_{\min }$ for depth greater than $\sim 3,505 \mathrm{~m}=1.167 \mathrm{D}$ -

$4,596+0.46\left(\mathrm{Pp}-\mathrm{P}_{\mathrm{cn}}\right)$

Where $\mathrm{P}_{\mathrm{cn}}=$ Normal Pore Pressure (Hydrostatic) in MPa. Equations (5) and (6) were calculated for our wells in the NDB. The results of the $\mathrm{SH}_{\min }$ calculations are displayed in Figures 2 and 3 to compare predictions from the Breckels, Holbrook and Eaton methods.

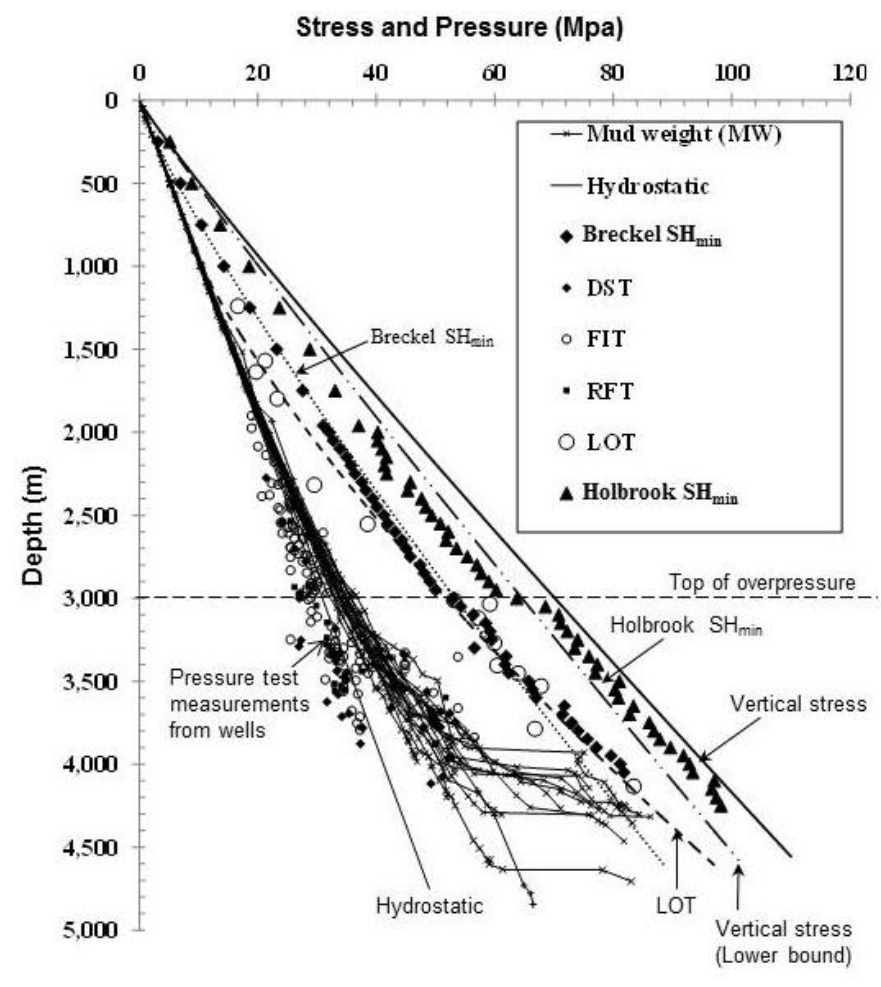

Fig. 2. Depth-stress and pressure plot shows the overestimation of the $\mathrm{SH}_{\mathrm{min}}$ by the Holbrook (1993) method approaching lithostatic. The overestimation becomes worse from the top of significant overpressure zone at $3,000 \mathrm{~m}$. Breckel $\mathrm{SH}_{\min }$ shows a similar rapid increase in stress at the same depth but very subtle. It indicates effect of overpressure on the $\mathrm{SH}_{\min }$ (Engelder, 1993; Tingay et al., 2003).

\section{ESTIMATION OF MAXIMUM HORIZONTAL STRESS MAGNITUDE}

The maximum horizontal stress $\left(\mathrm{SH}_{\max }\right)$ is the most difficult of the stress tensor components to determine. It requires knowledge of pore pressure, calibrated rock strength, $\sigma_{\mathrm{v}}$ and $\mathrm{SH}_{\min }$ data (Mark Tingay, personal communication; Reynolds et al., 2006). $\mathrm{SH}_{\max }$ can be estimated from image logs, the frictional limit to stress and DITF data, depending on the dominant faulting regime and tectonic history of the area (Zoback and Healy, 1984).

It becomes difficult to calculate $\mathrm{SH}_{\max }$ when the other two stress components $\left(\mathrm{SH}_{\min }\right.$ and $\left.\sigma_{\mathrm{v}}\right)$ vary significantly

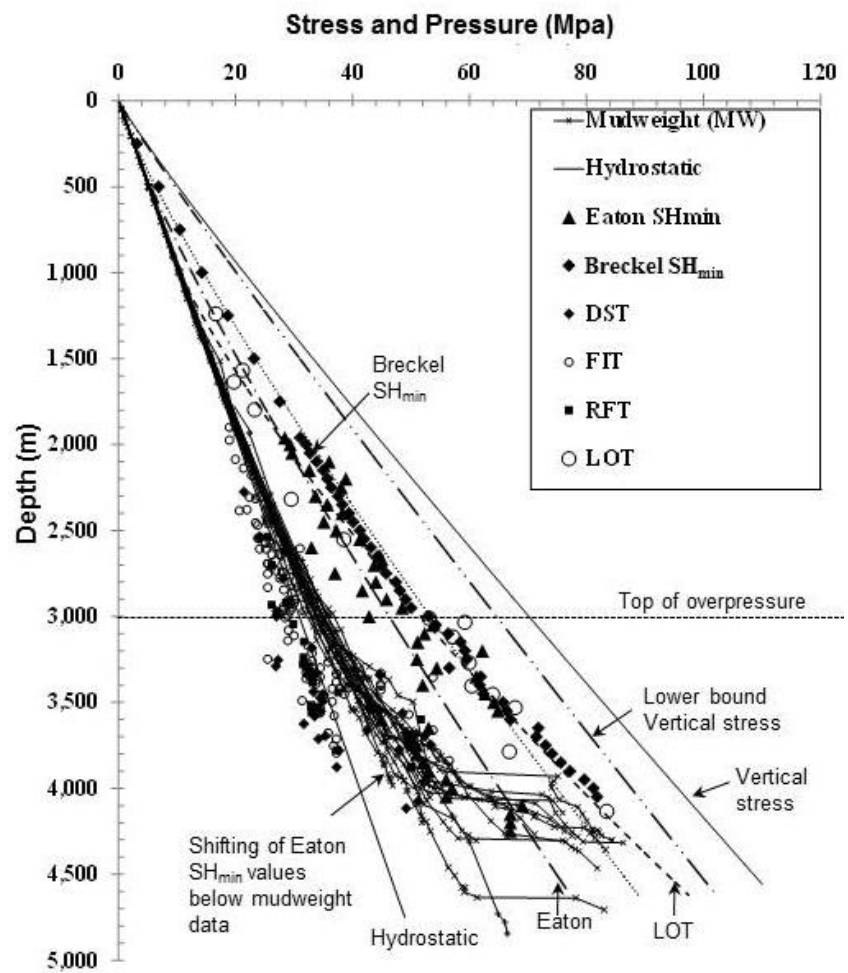

Fig. 3. Depth-stress and pressure crossplot shows the results of the Eaton and LOT methods for constraining minimum horizontal stress in the NNDB. Note that the mud weight is expected to be less than $\mathrm{SH}_{\min }$ to prevent hydraulic fracturing and lost circulation but in this case Eaton prediction are below mud weight from $3,500 \mathrm{~m}$ depth. Although the LOT data do not have any meaningful trend from top to bottom, the data seem to be consistent with the Breckel SHmin data for sedimentary basins (patterned after Gulf of Mexico) especially from $3,000 \mathrm{~m}$ depth supporting the applicability of the Breckel trend in the Niger Delta Basin.

across a basin (Streit and Hillis, 2004; Reynolds et al., 2006). The frictional limit to stress data, beyond which faulting occurs, provide an upper limit estimate for the $\mathrm{SH}_{\max }$ only in strike slip and reverse faulting regimes where $\mathrm{SH}_{\max }$ is the maximum principal stress (Reynolds et al., 2006). DITFs form at the orientation of the $\mathrm{SH}_{\max }$ where the circumferential stress exceeds compressive rock strength (Reynolds et al., 2005). The use of DITFs in near vertical wells for estimating $\mathrm{SH}_{\max }$ requires a large difference between $\mathrm{SH}_{\max }$ and $\mathrm{SH}_{\min }$. This is only possible in a strike-slip regime and not in a normal faulting regime such as the NDB (Moos and Zoback, 1990; Peska and Zoback, 19995, Reynolds et al., 2006). Hydraulic fracturing data from DITFs are lacking in many areas of the 
world (Breckels, 1981). Assuming a normal faulting regime is dominant in the NDB, the magnitude of the lower limit of vertical stress (from $21 \mathrm{MPa} / \mathrm{km}$ at $2 \mathrm{~km}$ to $22 \mathrm{MPa} / \mathrm{km}$ at 4 $\mathrm{km}$ ) was adopted as the upper limit of $\mathrm{SH}_{\max }$ magnitude (Figures 2 and 3). The lower limit of $\mathrm{SH}_{\max }$ closed up the upper limit of $\mathrm{SH}_{\min }$ which has also been poorly constrained. Thus, the magnitudes of the horizontal stresses are considered to be not very well constrained in this study.

\section{HORIZONTAL STRESS DIRECTION}

The direction of $\mathrm{SH}_{\max }$ can be calculated from earthquake focal mechanisms, analysis of borehole breakouts on image logs and four arm caliper data (a product of the dipmeter logging tool). The DITFs that are observable on image logs can also act as indicators for the $\mathrm{SH}_{\max }$ stress orientation. The direction of $\mathrm{SH}_{\max }$ is always at right angles to the $\mathrm{SH}_{\min }$, so an azimuthal constraint on one determines the other.

The NDB is not an ideal location to investigate the influence of the plate boundary forces on the intraplate stress field because the closest plate boundaries are about 600 nautical miles off the coast of Nigeria, and the region is considered a zone of low seismicity in a passive margin setting. This study has considered the use of earthquake focal mechanisms and borehole breakouts for the determination of in situ stress direction.

\section{A. Estimation of horizontal stress direction from tectonic activities}

The magnitude and direction of $\mathrm{SH}_{\max }$ can be estimated from well constrained focal plane mechanisms of crustal earthquakes by analysing the pattern of seismic radiation. The earthquake must be recorded at a sufficient number of seismic stations in order to determine the focal planes correctly (Zoback, 2010). It is important to understand that earthquake fault slip may alter the stress direction from the existing background stress (before the earthquake) to a new stress direction, as observed in the 1995 Kobe earthquake, Japan (Yamashita et al., 2004). This reinforces the need for a continuous measurement of stress directions, especially in a seismically active region.

In the study area, only four micro-earthquakes (earth tremors) have been registered by seismographic observations in the last 30 years, with surface wave intensities between 3.7 to 3.9 (Modified Mercalli scales, Akpan et al., 2010). Geological stress indicators such as the trend of fold axes and active reverse faults, and regional stress patterns (review of directions of stresses indicated in the region, such as contained in the World Stress Map) can also be used with caution to determine stress direction (Zoback, 2010). The NESW alignment of the volcanic cones shown in Fig. 6 is oblique to the ENE-WSW direction of the oceanic Ascension Fracture $(\mathrm{AF})$ and the East-West direction of the faults interpreted from the 3D seismic data in this study (Fig. 4). The change in the stress direction implied by the alignment of volcanic cones and the AFZ indicates a later development of stress beyond the detection limit of the oceanic crust.

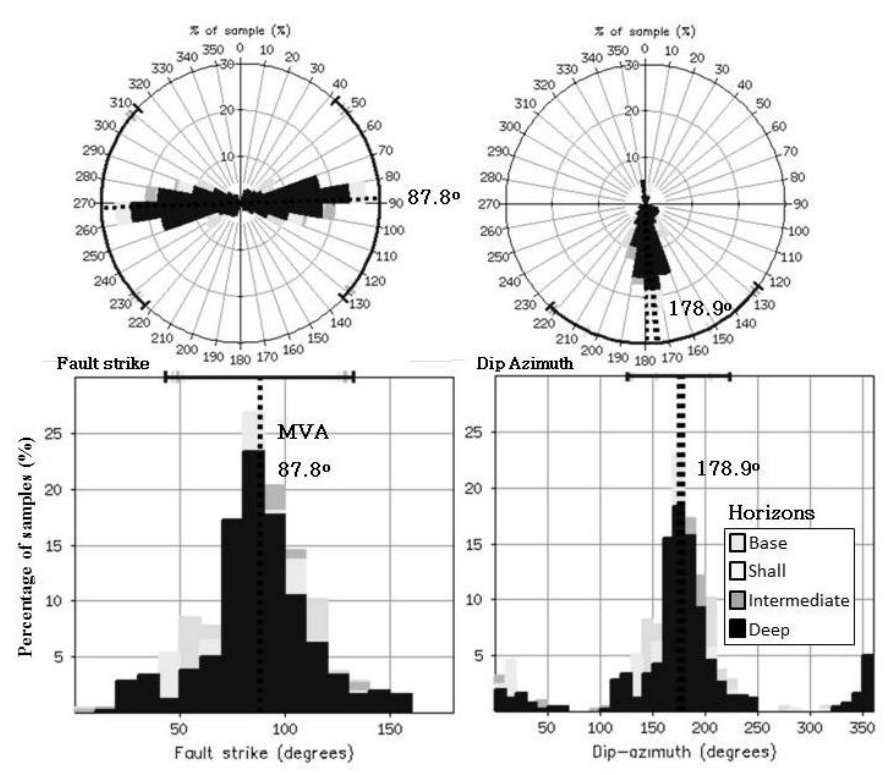

Fig. 4. The fault orientations for all the horizons interpreted from seismic data are plotted to show basin wide distribution of the fault strike and dip azimuth. The results show a near horizontal fault strike and vertical dip azimuth which are closer to the results obtained in the individual horizons.
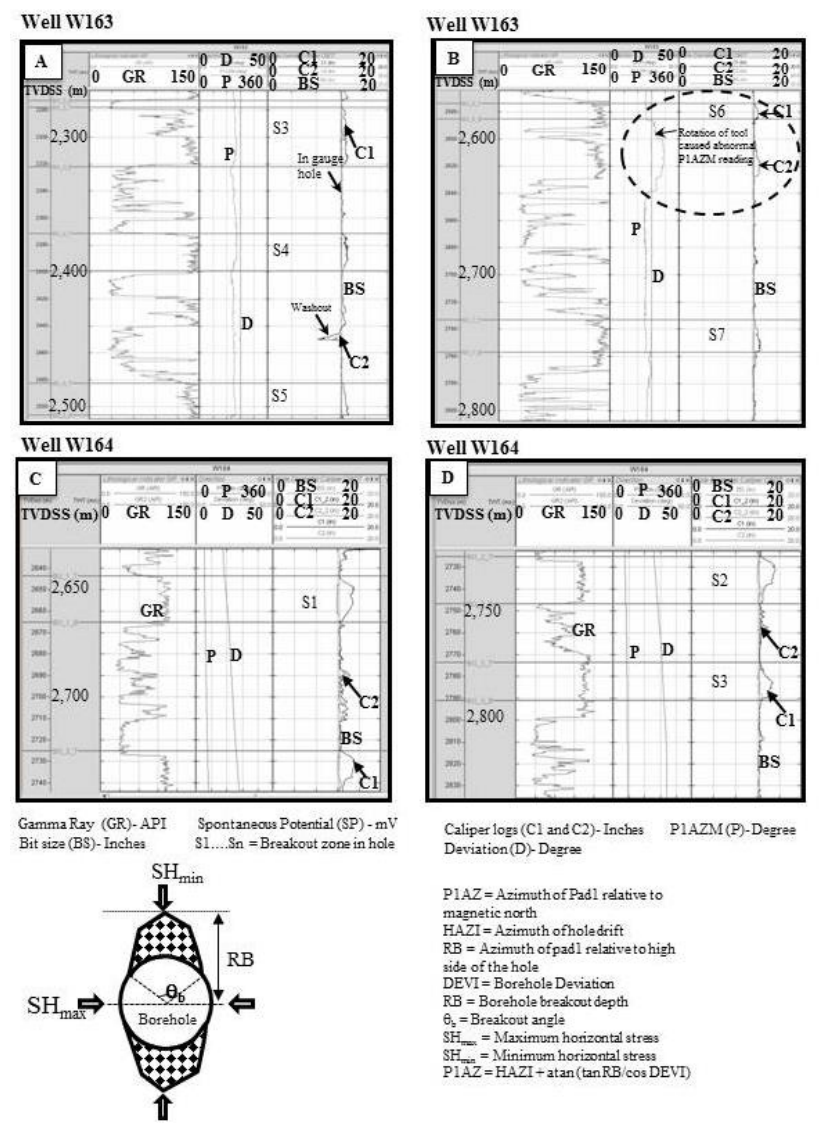

Fig. 5. The examples of borehole breakout analysis from caliper logs are shown in well W163 (A and B) and W164 (C and D) to illustrate the quality control criteria used in this study to identify breakout candidates in wells. The tool does not rotate (identified by swapping of the position of the two caliper logs relative to adjacent positions) where breakouts or keyseat are present. The breakout zone show that one pair of the caliper arms measures bit size and the other indicates a wider well bore diameter. 


\section{B. Estimation of horizontal stress direction from borehole caliper $\log s$}

Breakouts are wellbore enlargements with an ellipsoidal shape caused by stress-induced failure inside a wellbore. The breakouts form in a well whenever the circumferential stress exceeds the compressive rock strength (Reynolds et al., 2005).

A number of researchers have attributed conditions of breakout formation to variation in magnitudes of stresses in the borehole (Hoffman et al., 1979; Bell and Gough, 1979, 1982). The direction of spalling of the wellbore fragments in a near vertical well parallels the minimum horizontal stress direction. In a homogenous stress field, the direction of breakouts is usually consistent from the top to the bottom of well (Babcock, 1978; Plumb and Hickman, 1985; Zoback, 2010). Babcock (1978) investigated a similar trend in outcrops and reported that the azimuths of joints and fractures observed on outcrops also parallel those of borehole elongations. The stress field may be altered by tectonic activities at depth, such as those associated with salt bodies, active folding and slip on active faults (Zoback, 2010).

Evidence from breakouts found in wells shows that their formation is independent of depth, hole deviation, breakout azimuth, dip and existing fractures or joints. Substantial evidence has been provided in the literature (Babcock, 1978; Zoback et al., 1989; Zoback 2010) to show that stress field orientations determined from analysis of breakouts with four arm caliper data correlate very well with those derived from earthquake focal plane mechanisms, and young geologic indicators of deformations, e.g. fold axes. A breakout is interpreted from the caliper data using the measurements from the pairs of caliper arms (C1-3 and C2-4) in the well. The details of the measurements are shown in Fig. 5.

The elliptical cross section of the breakouts (bottom diagram in Fig. 5) and their azimuths indicate the direction of $\mathrm{SH}_{\min }$. Several researchers (e.g. Plumb and Hickman, 1985; Amato et al., 1995; Zajac et al., 1997; Reynolds et al., 2005; Reneiker et al., 2008; King et al., 2008; Tingay et al., 2008; Zoback 2010) have matured the understanding of the criteria used to identify breakout zones and differentiated them from other borehole enlargement features such as washouts and key seats (Fig. 5). Borehole breakouts were analysed in six wells located in the study area using data from four arm caliper tools; High Resolution Dipmeter Tool (HDT) and Oil-based Dipmeter Tool (OBDT). The key criteria used in the study to identify breakout zones on logs are listed below:

a) The rotation of the tool should show evidence of cessation in the zone of elongation.

b) The two caliper pairs should indicate tool rotation into and out of breakout zones (identifiable by a D-shaped balloon structure on $\log$ ).

c) The differential diameter (the difference in the measurement of the caliper readings at a point) must exceed that of bit size by at least $10 \%$.

d) The orientation of the breakout zones should not coincide with the high side of the borehole in wells deviated by more than $5^{\circ}$.

e) The length of the breakout zone (TVDSS) must be greater than $1 \mathrm{~m}$.

TABLE I

BOREHOLE BREAKOUT ANALYSIS FOR SIX WELLS

\begin{tabular}{|c|c|c|c|c|c|c|c|}
\hline $\begin{array}{l}\text { Breakout } \\
\text { Top Depth } \\
\text { mTVDSS }\end{array}$ & $\begin{array}{l}\text { Breakout } \\
\text { Bottom Depth } \\
\text { mTVDSS }\end{array}$ & $\begin{array}{l}\text { Breakout } \\
\text { Length } \\
(\mathrm{m})\end{array}$ & $\begin{array}{l}\text { Log Length } \\
\text { analysed } \\
(\mathrm{m})\end{array}$ & $\begin{array}{c}\text { Hole } \\
\text { Deviation } \\
\text { (deg) }\end{array}$ & $\begin{array}{c}\text { Breakout } \\
\text { Azimuth } \\
\text { (deg) }\end{array}$ & $\begin{array}{l}\text { Standard } \\
\text { deviation }\end{array}$ & $\begin{array}{c}\text { Breakout } \\
\text { Quality }\end{array}$ \\
\hline 2215.00 & 2229.58 & 14.58 & 2423.00 & 30.68 & 6.77 & 2.21 & B \\
\hline 2443.70 & 2475.20 & 31.50 & & 30.98 & 12.18 & & \\
\hline 2492.30 & 2507.19 & 14.89 & & 31.58 & 12.18 & & \\
\hline 2580.00 & 2589.38 & 9.38 & & 30.98 & 9.47 & & \\
\hline 2604.80 & 2647.20 & 42.40 & & 30.08 & 9.47 & & \\
\hline 2827.74 & 2846.19 & 18.45 & & 30.98 & 6.77 & & \\
\hline \multirow[t]{2}{*}{2923.18} & 2949.74 & 26.56 & & 29.47 & 6.77 & & \\
\hline & Total & 157.76 & & Mean & 9.09 & & \\
\hline 2632.97 & 2639.17 & 6.20 & 1758.21 & 8.80 & 84.00 & 7.26 & $\mathrm{C}$ \\
\hline 2692.50 & 2718.54 & 26.04 & & 10.83 & 80.00 & & \\
\hline 2744.17 & 2766.46 & 22.29 & & 10.64 & 76.80 & & \\
\hline 2792.71 & 2797.71 & 5.00 & & 10.00 & 87.00 & & \\
\hline \multirow[t]{2}{*}{2831.04} & 2876.67 & 45.63 & & 10.48 & 66.00 & & \\
\hline & Total & 105.16 & & Mean & 78.76 & & \\
\hline 2071.32 & 2082.78 & 11.46 & 1541.32 & 7.06 & 89.04 & 1.00 & B \\
\hline 2188.61 & 2216.53 & 27.92 & & 10.07 & 87.00 & & \\
\hline 2560.07 & 2576.11 & 16.04 & & 25.67 & 89.04 & & \\
\hline 2587.15 & 2593.19 & 6.04 & & 25.88 & 89.04 & & \\
\hline 2841.11 & 2853.40 & 12.29 & & 25.03 & 89.04 & & \\
\hline \multirow[t]{2}{*}{3030.28} & 3041.32 & 11.04 & & 24.17 & 87.11 & & \\
\hline & Total & 84.79 & & Mean & 88.38 & & \\
\hline 1465.46 & 1472.21 & 6.75 & 1200.00 & 47.00 & 84.86 & 0.88 & B \\
\hline 1589.21 & 1596.68 & 7.47 & & 47.40 & 87.43 & & \\
\hline 1891.50 & 1896.52 & 5.02 & & 47.14 & 87.43 & & \\
\hline 1896.94 & 1936.96 & 40.02 & & 47.86 & 84.86 & & \\
\hline 1947.89 & 1972.07 & 24.18 & & 46.43 & 84.86 & & \\
\hline \multirow[t]{2}{*}{1972.50} & 1981.77 & 9.27 & & 46.79 & 84.86 & & \\
\hline & Total & 92.71 & & Mean & 85.72 & & \\
\hline 2083.59 & 2102.10 & 18.51 & 1095.41 & 29.14 & 3.31 & 2.46 & B \\
\hline 2259.48 & 2272.89 & 13.41 & & 30.06 & 3.36 & & \\
\hline 2278.00 & 2322.05 & 44.05 & & 30.06 & 7.73 & & \\
\hline 2371.53 & 2399.30 & 27.77 & & 30.06 & 5.52 & & \\
\hline 2482.62 & 2506.24 & 23.62 & & 30.06 & 7.73 & & \\
\hline 2573.91 & 2585.40 & 11.49 & & 30.06 & 3.31 & & \\
\hline 2733.20 & 2757.14 & 23.94 & & 30.06 & 9.94 & & \\
\hline \multirow[t]{2}{*}{2850.04} & 2888.34 & 38.30 & & 29.75 & 9.94 & & \\
\hline & Total & 201.09 & & Mean & 6.36 & & \\
\hline 2643.83 & 2665.28 & 21.45 & 2566.00 & 19.75 & 53.62 & 4.65 & B \\
\hline 2725.28 & 2746.95 & 21.67 & & 26.94 & 54.10 & & \\
\hline 2773.83 & 2791.12 & 17.29 & & 31.75 & 62.84 & & \\
\hline 2843.83 & 2866.53 & 22.70 & & 33.98 & 65.64 & & \\
\hline 2890.28 & 2901.53 & 11.25 & & 34.84 & 63.90 & & \\
\hline 2985.91 & 3026.33 & 40.42 & & 40.81 & 56.30 & & \\
\hline \multirow[t]{2}{*}{3302.57} & 3319.24 & 16.67 & & 45.73 & 53.90 & & \\
\hline & Total & 151.45 & & Mean & 58.61 & & \\
\hline
\end{tabular}

See Table II for details of breakout quality ranking. A cumulative length of about 10,584 $\mathrm{m}$ of logs were analysed for breakouts, out of which $793 \mathrm{~m}$ were breakouts representing approximately $8 \%$ of length of $\operatorname{logs}$ analysed. 
f) The reading of the smaller caliper should be close to the bit size or show less variation than the larger caliper.

g) The azimuth of the highest caliper reading must be different by more than $10^{\circ}$ from the hole deviation azimuth.

The choice of wells to use for breakout analysis in this study was limited to those wells that have good caliper log data and high quality boreholes breakouts. Wells with a maximum deviation of less than $15^{\circ}$ from vertical have been suggested to be the preferred choice for breakout analysis (Amato et al., 1995) because breakout orientations can rotate in inclined boreholes and may not give the true direction of horizontal stress (Mastin, 1988; Peska and Zoback, 1995). The deviation angle of well W150 varies from approximately $9^{\circ}$ to $10^{\circ}$ from the top to the bottom of the well while the remaining five wells deviated from $7^{\circ}$ to $47^{\circ}$ (Table I). The directions of borehole breakouts in deviated boreholes depend on the following: type of faulting regime, deviation angle $(\varnothing)$ of the borehole axis from vertical, relative magnitudes of the three principal stresses $\left(\mathrm{SH}_{\min }, \mathrm{SH}_{\max }\right.$ and $\left.\sigma_{\mathrm{v}}\right)$ and the angle $\Theta$ between the horizontal projection of the borehole axis and the direction of $\mathrm{SH}_{\min }$. Mastin (1988) investigated the effect of borehole deviation on breakouts in different faulting regimes and the result indicates that the influence of well deviation on breakouts in strike slip faulting regime seems insignificant compared with those of normal and thrust faulting regimes. For example, a borehole must deviate at least $35^{\circ}$ from the vertical in the strike slip faulting regime before horizontal projection of the breakout direction differs by more than $10^{\circ}$ from $\mathrm{SH}_{\text {min }}$. However, in the normal and thrust faulting regimes, the change in the $\mathrm{SH}_{\text {min }}$ direction depends on the local magnitude of the horizontal differential stress $\left(\mathrm{SH}_{\max }-\mathrm{SH}_{\min }\right)$ in the well. A very high horizontal differential stress has a tendency to cause a substantial change in breakout direction irrespective of the deviation angle (Mastin, 1988).

The stress data were plotted on the World Stress Map

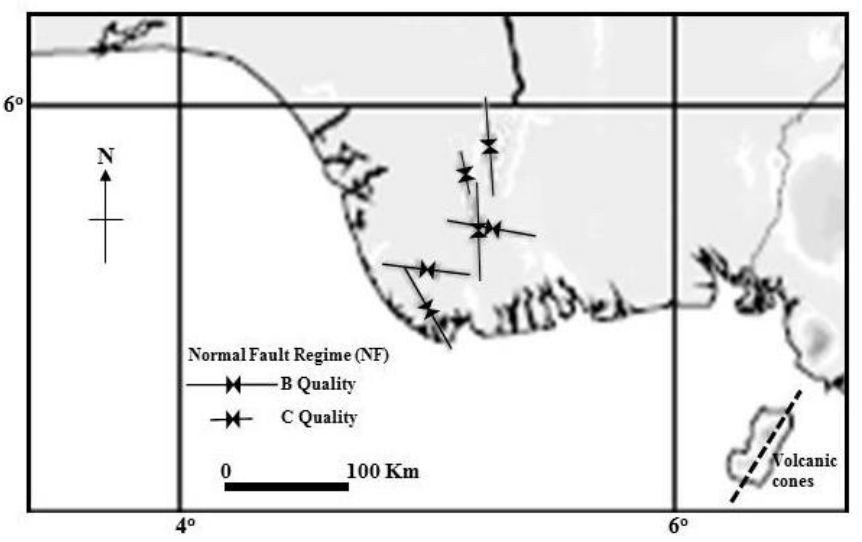

Fig. 6. The map shows the plots of maximum horizontal stress directions from analysis of 6 borehole breakouts in the Niger Delta Basin (see Table II for details). The differential stress direction between the alignment of volcanic cones (located south east of Nigeria) and the stress orientations constrained in this study implies a diverse range of stress orientations as a result of multiple sources of stress in the region.

(Fig. 6) for a regional overview and also superimposed on a structural map (Fig. 7) to show the relationship between the stress data and the structural faults.
Only one breakout in well W164 occurred below the top of overpressure in the basin $(3,000 \mathrm{~m})$, all other breakouts occurred from $1,465 \mathrm{~m}$ to $3,000 \mathrm{~m}$, suggesting the effect of overpressure on the breakout direction in the six wells is not significant.

\section{DISCUSSION AND CONCLUSION}

The Holbrook method overestimated the $\mathrm{SH}_{\min }$ but a continuous profile of porosity data (preferably from cores) from the top to the bottom of wells may increase the validity of the prediction. The scattering of the $\mathrm{SH}_{\text {min }}$ values estimated from the Eaton (1969) method and Leak Off Test (LOT) data from top to bottom (Figures 2 and 3 ) is indicative of varying $\mathrm{SH}_{\text {min }}$ gradient with depth in the basin. In a similar study, Reynolds et al. (2006) interpreted the scattering of the minifrac data in the Cooper-Eromanga Basin, Australia to be a reflection of genuine variation of the $\mathrm{SH}_{\min }$ in the area. Thus, the lower limit of the LOT data has been used to approximate

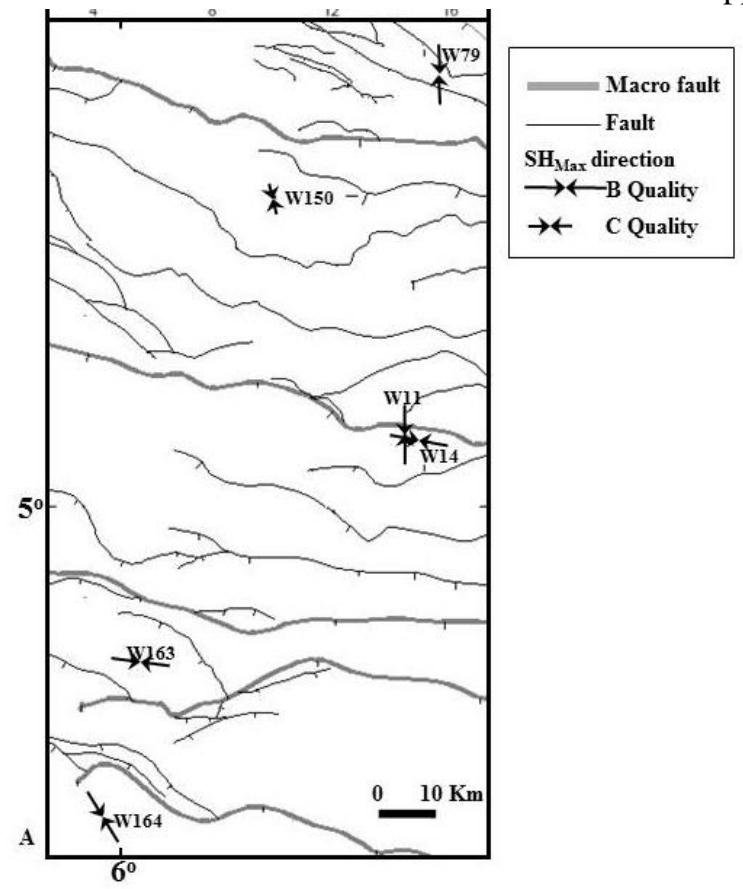

Fig. 7. Map showing direction of maximum horizontal stress estimated from analyses of 39 breakouts in 6 wells.

$\mathrm{SH}_{\text {min }}$ magnitude $(14.5 \mathrm{MPA} / \mathrm{km}$ @ $2 \mathrm{~km}$ to $19.8 \mathrm{MPa} / \mathrm{km}$ at 4 $\mathrm{km})$ in the NDB. The LOT line shown in Fig. 4 compares favourably with the $\mathrm{SH}_{\min }$ estimated from the Breckels et al. (1981) method.

The differential maximum horizontal stress gradient from 2 $\mathrm{MPa} / \mathrm{km}$ at $2 \mathrm{~km}$ to $22 \mathrm{MPa} / \mathrm{km}$ at $4 \mathrm{~km}$ is a reflection of variation of rock density with depth. Wright (1978) reported that the ENE-WSW trending Romanche Fracture Zone which separates the North and South Atlantic oceans, and the Chain Fracture Zone are the principal lines of weakness in the African continental crust. Some authors (Adepelumi et al., 2008; Anifowose et al., 2010; Babalola et al., 1991) suggested a link of the Chain Fracture Zone with regional onshore faults particularly the NE-SW trending Ifewara-Zungeru complex fault systems which cut across old metamorphic basement complex rocks and younger sedimentary rocks. The 

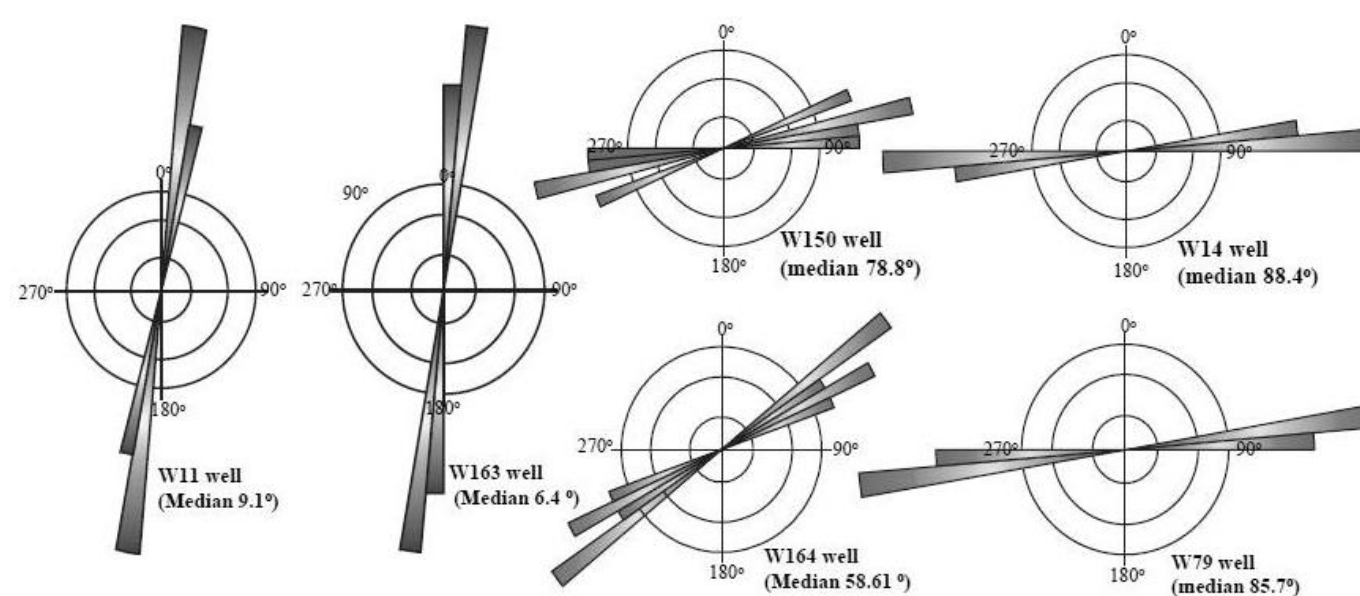

Fig. 8. The different directions of the petals of the rose plots in all the six wells suggest non uniformity distribution of borehole breakouts in the basin with both depth and space.

mechanism of fault reactivation and the sources of stress are poorly understood. The large age difference between the younger Niger Basin and the old basement complex rocks makes it difficult to compare their in situ stresses. This is because the response of rocks to external stress depends on the timing of the deformation. Only a few properties of rocks in outcrops actually preserved features that will reveal events at the time of deformation. This can be relatively compared

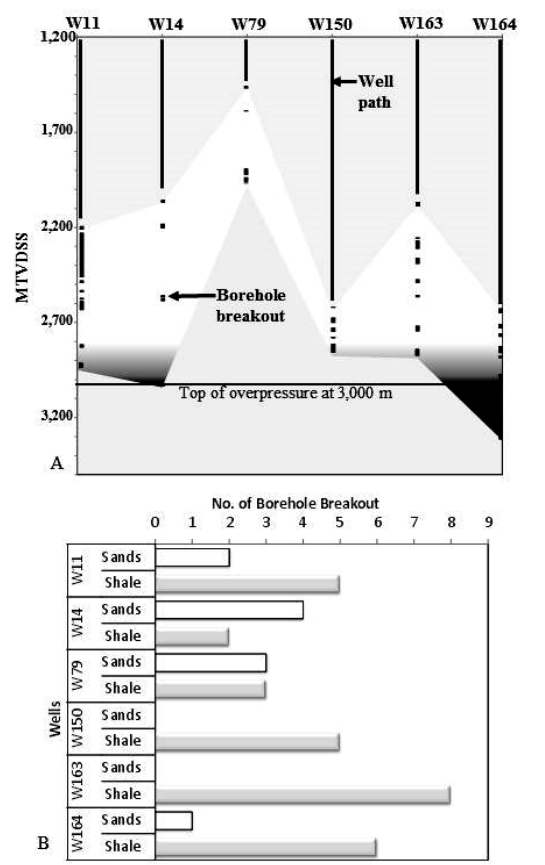

Fig. 9. The bar charts in (B) shows that the breakouts are independent of lithologies but seem to occur slightly more in shales than sands. to a subsiding sedimentary basin which preserved deformation episodes for easy estimation (Bjørlykke, 2006). For example, the results of four horizons interpreted from 3D seismic data in the Niger Delta Basin show a near vertical orientation and an average east-west strike (Fig. 4). The direction of the faults found in the onshore Niger Delta Basin show minimal consistency with the NE-SW orientation of the regional faults identified on the outcrops in the region. We propose that the repeated earth tremors felt in Nigeria are likely to be the adverse effects of the reactivation of rifted continental crust linking the regional onshore faults along major, deeper lineaments.

It is apparent that the $\mathrm{SH}_{\max }$ directions for wells W14, W163 and W164 parallel the nearby faults. The wells W79 and W150 located in the northern area exhibit a north-south $\mathrm{SH}_{\max }$ orientation, almost perpendicular to the nearby faults
(Fig. 7). This change in the observed stress orientation that is inconsistent with the faults indicates a possible different source of stress. There is a minor rotation of the $\mathrm{SH}_{\max }$ direction from the east-west orientation in the south of the basin to northsouth direction in the north of the basin. A disparity in the local stress direction from a known regional trend may be attributed to lateral changes in the elastic properties of rocks, structural variations and geologic structures (Bell, 1996; Mandal, 1997; Reynolds, 2005). Based on the conditions of breakout formation discussed earlier, under normal circumstances, breakout is expected to occur more in low strength rocks than high strength rocks. However, borehole breakouts preferentially formed more in shale than sandstone units in the NDB (Fig. 9B). The propagation of breakouts from sandstone to shales in some well shows that formation of borehole breakout is independent of lithology. There are possible explanations for the occurrence of breakout in shale units (Fig. 9): (a) the shales are highly undercompacted and thus less weak than the sandstone units; or (b) preferential occurrence of breakout in a higher strength rock unit with higher horizontal stress magnitude than the surrounding lower strength rock units (Evans et al., 1989; Nelson et al., 2006). Explanation (b) may not be realistic in the basin due to the low seismicity in the region but there are possibilities of having a higher horizontal stress in depth higher than the one constrained in this study.

There is a clear opportunity to use the stress data provided in this study to assess fault stability in the region.

\section{ACKNOWLEDGMENT}

The authors wish to express gratitude to the Ministry of Petroleum Resources (MPR), Nigeria for giving authority to access the data for this study. We are especially indebted to David Macdonald (research co-supervisor of the corresponding author), Judith Christie, John Still and Jim Marr in the Department of Geology and Petroleum Geology, University of Aberdeen and Mark Tingay, formerly of the University of Adelaide, now at Chevron (Australia). This study has been aided by the provision of access to software at the University of Aberdeen by Halliburton (Seisworks, Zmap and Stratworks), Badleys (Traptester), Ikon (Rockdoc), and CGG Veritas (Elog, Strata and AVO).

\section{REFERENCES}

[1] A. A. Adepelumi, B. D. Ako, T. R. Ajayi, A. O. Olorunfemi, M. O. Awoyemi, and D. E Falebita, "Integrated geophysical studies of the 
Ifewara transcurrent fault system, Nigeria," Journal of African Earth Science, 52, pp. 161-166, 2008.

[2] A. Amato, and P. Montone, "State of stress in southern Italy from borehole breakout and focal mechanism data," Geophysical Research letters, 22 (23), pp. 3119-3122, December 1995.

[3] A. Whiteman, Nigeria: Its Petroleum Geology, Resources and Potential. London, Graham and Trotman, p. 394, 1982.

[4] A. Y. Anifowose, M. I. Oladapo, O. U. Akpan, C. O+. Ologun, O. O. Adeoye-Oladapo, S. Y. Tsebeje, and T. A. Yakubu, "Systematic multitechnique mapping of the southern flank of Iwaraja fault, Nigeria," Journal of Appl. Sci. Tech., 15 (1-1), pp. 70-76, 2010.

[5] B. A. Eaton, "Fracture gradient prediction and its application in oilfield operations," Journal of Petroleum Technology, 246, pp. 1353-1360, 1969.

[6] B. D. Evamy, J. Haremboure, P. Kamerling, W. A. Knaap, F. A. Molloy, and P.H. Rowlands, "Hydrocarbon habitat of tertiary Niger delta," AAPG Bulletin, 62, pp. 1-39, January 1978.

[7] B. J. Zajac, and J. M. Stock, "Using borehole breakouts to constrain the complete stress tensor: Results from the Sijan Deep Drilling project and offshore Santa Maria Basin, California," Journal of Geophysical Research, 102 (B5), pp. 10083-10100, 10 May 1997.

[8] E. A. Babcock, "Measurement of subsurface fractures from dipmeter logs," AAPG Bulletin, 62 (7), pp. 1111-1126, 1978.

[9] E. M. Anderson, The dynamics of faulting and dyke formation with applications to Britain. Edinburgh, Oliver and Boyd, p. 206, 1951.

[10] E. Nelson, R. Hillis, M. Sandiford, S. Reynolds, and S. Mildren, "Present-day state-of-stress of southeast Australia," APPEA Journal, pp. 283-306, 2006

[11] E. O. Adewole, D. I. M. Macdonald, and D. Healy, "Estimating density and vertical stress magnitudes using hydrocarbon exploration data in the onshore Northern Niger Delta Basin, Nigeria: Implication for overpressure prediction," Unpublished.

[12] H. Doust, and E. Omatsola, "Niger Delta, in Edwards, J. D., and Santogrossi, P. A., eds., Divergent/passive Margin Basins, AAPG Memoir 48: Tulsa, America Association of Petroleum Geologists, pp. 73-89, 1990.

[13] I. M. Breckels, and H. A. M. Van Eekelen, "Relationship between horizontal stress and depth in sedimentary basins," presented at $56^{\text {th }}$ Annual fall Technical Conference, Society of Petroleum Engineers of AIME, San Antonio, Texas, October 5-7, 1981, Paper SPE10336.

[14] J. B. Wright, "Fracture systems in Nigeria and initiation of fracture zones in the south Atlantic," Tectonophys., vol. 34, pp. 13-47, 1978.

[15] J. E. Streit, and R. R. Hillis, "Estimating fault stability and sustainable fluid pressures for underground storage of $\mathrm{CO}_{2}$ in porous rock," Energy, 29, pp. 1445-1456, 2004.

[16] J. Hospers, "Gravity field and structure of the Niger Delta, Nigeria, West Africa." Geol. Soc. America Bull., 76, pp. 407-422, 1965.

[17] J. Hosper, "The geology of the Niger Delta area," in The geology of the East Atlantic continental margin, eds. Delany F. M. Institute of geological sciences report No. 70/16, pp. 121-142, 1971.

[18] J. Reinecker, M. R. P. Tingay, and B. Muller, "Borehole breakout analysis from four-arm caliper logs," in World stress map project, 2008 - Guidelines: Four arm Caliper logs, 2008.

[19] J. S. Bell, "Petro Geoscience 1, in situ stresses in sedimentary rocks (part 1): measurement techniques," Geoscience Canada, 23, pp. 85-100, 1996.

[20] J. S. Bell, "The stress regime of the Scotian Shelf offshore eastern Canada to 6 kilometers depth and implications for rock mechanics and hydrocarbon migration," in Maury, V., Fourmaintraux, D. (Eds.), Rock at Great Depth. Balkema, Rotterdam, pp. 1243-1265, 1990.

[21] K. Bjørlykke, "Effects of compaction processes on stresses, faults and fluid flow in sedimentary basins: examples from the Norwegian margin," Geological Society, London, Special Publications, 253, pp. 359-379, 2006

[22] K. Burke, "Longshore drift, submarine canyons and submarine fans in development of Niger delta," AAPG Bull., 56, pp. 1975-1983, 1972.

[23] K. Burke, "Recent faulting near the Volta Dam," Nature, 231, pp. 49440, 1971.

[24] K. C. Short, and A. J. Stauble, "Outline of geology of Niger Delta," AAPG Bulletin, 51, pp. 761-779, 1967.

[25] K. F. Evans, T. Engelder, and R. A. Plumb, "Appalachian stress study 1. A detailed description of in situ stress variations in Devonian shales of the Appalachian Plateau," Journal of Geophysical Research, 94, pp. 7129-7154, 1989

[26] K. J. Weber, and E. M. Daukoru, "Petroleum geological aspects of the Niger Delta. Nigeria Journal of Mining and Geology," 12, pp. 9-22, 1975.

[27] K. J. Weber, "Hydrocarbon distribution patterns in Nigerian growth fault structures controlled by structural style and stratigraphy, "Journal of Petroleum Science and Engineering, 1, pp. 91-104, 1987.

[28] K. J. Weber, "Sedimentological aspects of oil field in the Niger Delta," Geologie en Mijnbouw, 50, pp. 559-576, 1971.

[29] L. Mastin, "Effect of borehole deviation on breakout orientations," Journal of Geophysical Research, 93(B8), pp. 9187-9195, August 10, 1988

[30] M. D. Zoback, and J. H. Healy, "Friction, faulting and in situ stress," Annu. Geophys., 2 (6), pp. 689-698, 1984.

[31] M. D. Zoback, Reservoir Geomechanics. Cambridge University Press, the Edinburgh Building, Cambridge, CB2 8RU, United Kingdom, p. 449. (ed.) 2010

[32] M. L. Zoback, M. D. Zoback, et al., "Global patterns of tectonic stress. Nature," 341, pp. 291-298, 28 September, 1989.

[33] M. R. P. Tingay, R. R. Hillis, C. K. Moley, R. C. King, and R. E. Swarbrick, "Present-day stress and neotectonics of Brunei: Implications for petroleum exploration and production," AAPG Bulletin, 93, pp. 75100, 2008.

[34] M. R. P. Tingay, R. R. Hillis, C. K. Morley, R. E. Swarbrick, and E.C. Okpere, "Variation in vertical stress in the Baram Basin, Brunei: Tectonic and geomechanical implications," Journal of Marine and Petroleum Geology, 20, pp. 1201-1212, 2003.

[35] M. R. P. Tingay, University of Adelaide, Australia, private communication, July 2011.

[36] N. N. Ambraseys, and R. D. Adams, "Seismicity of West Africa," Ann. Geophys., 4, pp. 679-702, 1986.

[37] O. O. Babalola, and M. Gipson, "Aeromagnetic anomalies and discordant lineations beneath the Niger Delta: Implication for new fracture zones and multiple sea floor spreading directions in the MesoAtlantic Gulf of Guinea Cul-de-sac," Geophysical Research letters, 18(6), pp. 1107-1110, June 1991

[38] P. J. Merki, "Structural geology of the Cenozoic Niger delta," in Proceedings of African Geology Conference, Ibadan, Nigeria, Ibadan Univ. Press, pp. 635-646, 1972.

[39] P. Mandal, A. Manglik, and R. N. Singh, "Intraplate stress distribution induced by topography and crustal density heterogeneities beneath the Killari, India region," Journal of Geophys. Res., 102, pp. 11719-11729, 1997.

[40] P. W. Holbrook, D. A. Maggiori et al., "Real time pore pressure and fracture gradient evaluation in all sedimentary lithologies," presented at Offshore European Conference, Aberdeen, Scotland, Society of Petroleum Engineers, 1993, Paper SPE 26791.

[41] R. C. King, R. Hillis, and S. D. Reynolds, "In situ stresses and natural fractures in the Northern perth basin, Australia," Australian Journal of Earth Sciences, 55, pp. 685-701, 2008.

[42] R. H. Sibson, "Frictional constraints on thrust, wrench and normal faults," Nature, 249, pp. 542-544, 1974.

[43] R. Stoneley, "The Niger Delta region in the light of the history of continental drift. Geology Magazine," 103, pp. 385-397, 1966.

[44] S. D. Reynolds, S. Mildren, R. Hillis, J. J. Meyer, and T. Flottmann, "Maximum horizontal stress orientations in the Cooper Basin, Australia: implications for plate-scale tectonics and local stress sources," Geophys. J. Int., 2005, 160, pp. 331-343, 2005.

[45] S. D. Reynolds, S. D Mildren, R. R. Hillis, J. J. Meyer, "Constraining stress magnitudes using petroleum exploration data in CooperEromanga basins, Australia," Tectonophysics, 415, pp. 123-140, 23 February, 2006.

[46] T. Engelder, Stress regimes in the lithosphere. Princetown University press, 1993. 
E. O Adewole earned his first degree in applied geology in Federal University of Technology, Akure, Nigeria in 1992 and a second degree in Petroleum Geology in University of Port Harcourt, Port Harcout, Nigeria in 2002.

He worked as a senior geologist and a geophysicist with exploration division of Nigeria Agip Oil Co. Ltd, Port Harcourt, Nigeria (subdivision of ENI, Italy) for over 8 years. He is currently a scholar of Niger Delta Development Commission in University of Aberdeen, Aberdeen.

Mr Adewole is a professional member of Society of Exploration Geophysicists (SEG) and American Association of Petroleum Geologists (AAPG). 